\title{
Bacteriological Quality of Vegetable Salads Sold at Restaurants Within Okada Town, Edo State, Nigeria.
}

\author{
Osamwonyi Osarobo Uwamere ${ }^{1}$, Obayagbona Omoregbe Nosa $^{2}$, Aborisade \\ Tope Wakil ${ }^{3}$, Olisaka Ngozi Frances ${ }^{4}$, Uwadiae Eseosa ${ }^{4}$, Igiehon Ozede \\ Nicholas ${ }^{5}$ \\ 1. Department of Microbiology, Faculty of Sciences, University of Calabar, Calabar, Cross Rivers State, \\ Nigeria. \\ 2. Microbiology Laboratory, Edo Environmental Laboratory and Consults, Palm House Annex, Benin City, \\ Edo State, Nigeria. \\ 3. Department of Microbiology, Faculty of Basic Sciences, Igbinedion University, Okada, Edo State, Nigeria. \\ 4. Microbiology and Biochemistry Laboratory, Faculty of Basic Sciences, Benson Idahosa University, Benin \\ City, Edo State, Nigeria. \\ 5. Department of Microbiology, Faculty of Life Sciences, University of Benin, Benin City, Edo State, Nigeria.
}

\begin{abstract}
Eighteen samples of vegetable salads sold from three restaurants located at Okada town, Edo State were collected and their bacteriological attributes were investigated using routine methods. The mean heterotrophic and coliform counts recorded for the salad samples ranged from $1.46 \times 10^{4}$ to $2.80 \times 10^{4} \mathrm{CFU/g}$, and $1.46 \times 10^{4}$ to $2.84 \times 10^{4} \mathrm{CFU} / \mathrm{g}$ for food centre A. THC and TCC counts $\left(1.74 \times 10^{4}\right.$ to $2.36 \times 10^{4} \mathrm{CFU} / \mathrm{g}$ and $1.36 \times 10^{4}$ to $2.10 \times 10^{4} \mathrm{CFU/g}$, respectively were obtained for vegetable salads collected from Eatery $B$. Microbial counts for salads obtained from food service center C varied from $2.08 \times 10^{4}$ to $2.60 \times 10^{4} \mathrm{CFU} / \mathrm{g}$ and $1.12 \times 10^{4}$ to $2.90 \times 10^{4} \mathrm{CFU} / \mathrm{g}$ for THC and TCC, respectively. The differences between the mean bacterial counts were statistically insignificant $(P>0.01)$. Twelve non hemolytic bacterial isolates were identified; Acinetobacter sp., Bacillus sp., Pseudomonas aeruginosa, Proteus mirabilis, Serratia marcescens, Staphylococcus epidermidis, Micrococcus leutus, Enterobacter aerogenes, Escherichia coli, Citrobacter freundii, Klebsiella pneumoniae and Klebsiella oxytoca. E. aerogenes had the highest percentage of occurrence (56\%) amongst the isolates. It is recommended that sellers and food handlers within the respective restaurants should make conscious efforts to decontaminate and properly handle the vegetables prior to its salad preparation.
\end{abstract}

Key words: Coliforms Heterotrophic, Restaurants, Vegetable Salads

\section{Introduction}

Salad is a term broadly applied to many food preparations that have mixture of chopped or sliced ingredients which may be mostly fruits or vegetables [1]. Common vegetables used in salad include cucumber, pepper, tomatoes, onions, red onions, carrots, spring onions and radishes. Other ingredients such as olives, mushrooms, hard- boiled egg, green beans, cheese, meat or seafood are sometimes added to salads. Fruits and vegetables are well-known sources of useful nutrients in the form of vitamins, minerals, dietary fibers and other phyto nutrients including flavonoids, carotenoids and phenolic compounds that may lower the risk of cancer, heart disease and others illnesses [2]. Consumption of fresh fruits and vegetables is encouraged and a recommendation of at least five servings per day has been made to American consumers [2].

Vegetables have been associated with outbreaks of foodborne disease in many countries [3]. Organisms involved include bacteria, viruses and parasites [4]. The outbreaks vary in size from a few persons affected to many thousands [3]. Contamination of vegetables may take place at all stages during pre and post harvest techniques [3]. Unsafe water used for rinsing the vegetables and sprinkling to keep them fresh is also a source of contamination [5]. Other possible sources of microorganisms include soil, feces (human and animal origin), ice, animals (including insects and birds), handling of the product, harvesting and processing equipment and transport [6].

Pathogens isolated from vegetable salad include; Staphylococcus aureus, Enterobacter spp., Klebsiella spp., Salmonella typhi, Serratia spp., Providencia spp., Pseudomonas aeruginosa, Yersinia enterocolitica, Aeromonas hydrophila and Shigella sonnei [7]. The term coliform represents a group of species from several genera, namely, Escherichia, Enterobacter, Klebsiella, Citrobacter, and probably Aeromonas and Serratia [8]. The main reason for grouping them together is their many common characteristics. They are all Gram-negative, non spore forming rods; many are motile, facultative anaerobes resistant to many surface-active agents, and ferment lactose to produce acid and gas within $48 \mathrm{~h}$ at $32^{\circ} \mathrm{C}$ or $35^{\circ} \mathrm{C}$ [8]. Some species can grow at higher 
temperature $\left(44.5^{\circ} \mathrm{C}\right)$, whereas others can grow at $4{ }^{0} \mathrm{C}$ to $5^{0} \mathrm{C}$. All are able to grow in foods except in those that are at $\mathrm{pH} \leq 4.0$ (a few that are acid resistant can grow or survive) and $A w \leq 0.92$ [8].

Microbes associated with fresh-cut fruit and vegetable products can vary greatly in accordance with the produce type and storage conditions. Temperature plays a significant role in determining the nature of the micro flora associated with refrigerated fresh-cut fruits and vegetables [2]. The numbers and kinds of microorganisms associated with fresh-cut produce are highly variable. Mesophilic bacteria from plate count studies typically range from $103 \times 10^{1}$ to $109 \times 10^{1} \mathrm{CFU} / \mathrm{g}$ [2]. Total counts of products after processing range from $103 \times 10^{1}$ to $106 \times 10^{1} \mathrm{CFU} / \mathrm{g}$ [9]. Microbial hazards continue to be one of the biggest threats to food safety [10]. The implications of the microbial contamination and growth on vegetable produce include spoilage, decreased sensory appeal and decreased shelf life. However, coliforms are expected to be present in many raw foods and food ingredients of animal and plant origin [8]. Also, the occurrence of some coliforms of non fecal origin and their ability to grow in many foods reduces the specificity of coliforms as an indicator of fecal contamination in raw foods [8]. However, coliforms are commonly used bacterial indicator of sanitary quality of foods and water and are also utilized as indicators of microbial pollution as they are common inhabitants of both animal and human guts [11].

The aim of this study was to evaluate the bacteriological quality of ready to eat vegetable salads sold within three restaurants located at Okada town, Ovia north east local government area, Edo State, Nigeria.

\section{Materials and Methods}

\subsection{Sample collection}

Two vegetable salad servings were collected from each of the respective restaurant at both the morning time (10:00am) and evening time (4:00pm) during a three month period (May-July, 2012). A grand total of 18 vegetable salads were purchased from the various restaurants. The vegetable salads were dispensed onto sterile plastic containers and placed in coolers which contained ice packs. The coolers were transported to the laboratory for immediate analysis. Microbiological analysis was performed within 1 to $3 \mathrm{hr}$ of specimen collection.

\subsection{Stock preparation and enumeration of microbial counts}

A stock solution of $10^{-1}$ dilution was prepared by taking $10 \mathrm{~g}$ of each salad sample, mixed with $90 \mathrm{ml}$ of sterile peptone water and homogenized in a sterilized blender for $3 \mathrm{~min}$. The suspension was filtered through sterile filter paper Whatmann No. 1, and the filtrate was received in a sterilized labeled conical flask. Nine ml of the filtrate was transferred onto sterile test tube. This was serially diluted up to $10^{-8}$ using peptone water as diluent [12]. About $0.1 \mathrm{ml}$ aliquot from each dilution was transferred onto Petri dishes and the heterotrophic bacterial and total coliform counts (duplicate) were determined using the pour plate technique [12, 13]. Culture media utilized were; nutrient agar (Oxoid Ltd., Basing Stoke Hants, England) used for determination of the total heterotrophic count and eosin methylene blue agar (Oxoid Ltd., Basing Stoke Hants, England) used in enumeration of the total coliforms. The nutrient agar plates and eosin methylene blue agar plates were incubated at $35^{\circ} \mathrm{C}$ for 48 hours. Discrete bacterial colonies on nutrient agar and eosin methylene blue agar plates were sub cultured onto freshly prepared nutrient agar plates. These pure cultures were also streaked onto nutrient agar slants and stored at $5^{\circ} \mathrm{C}$. The sub cultured microbial isolates were identified by their colonial and cell morphology, Gram reaction and a combination of standard biochemical tests [13-17]. Also, the hemolytic activity of the identified bacterial isolates was evaluated using sheep erythrocytes. Pure bacterial cultures were streaked on a freshly prepared $5 \%$ sheep blood agar and incubated overnight $(18-24 \mathrm{hr})$ at $37^{\circ} \mathrm{C}$. The incubated plates were examined for visible signs of hemolysis [17].

\subsection{Statistical analysis}

Analysis of variance (ANOVA) of the respective mean bacterial counts obtained for the vegetable salad samples were determined $(\alpha=0.01)$ using SPSS version 20.

III. TABLE

Table 1: Total heterotrophic bacterial and coliform counts (mean $\left.\times 10^{4} \mathrm{CFU} / \mathrm{g}\right)$ of the vegetable salad samples

\begin{tabular}{|c|c|c|c|c|c|c|}
\hline $\begin{array}{l}\text { Sampling } \\
\text { months }\end{array}$ & May & & \multicolumn{2}{|c|}{ June } & \multicolumn{2}{|c|}{ July } \\
\hline $\begin{array}{l}\text { Sampling points } \\
\text { (Restaurants) }\end{array}$ & THC & TCC & THC & TCC & THC & TCC \\
\hline $\mathrm{A}_{1 \text { (morning) }}$ & $1.46^{\mathrm{a}}$ & $2.24^{\mathrm{a}}$ & $2.20^{\mathrm{a}}$ & $2.06^{\mathrm{a}}$ & $2.34^{\mathrm{a}}$ & $1.46^{\mathrm{a}}$ \\
\hline $\mathrm{A}_{2 \text { (evening) }}$ & $1.92^{\mathrm{a}}$ & $2.84^{\mathrm{a}}$ & $2.68^{\mathrm{a}}$ & $2.30^{\mathrm{a}}$ & $2.80^{\mathrm{a}}$ & $1.90^{\mathrm{a}}$ \\
\hline $\mathrm{B}_{1 \text { (Morning) }}$ & $1.80^{\mathrm{a}}$ & $1.92^{\mathrm{a}}$ & $1.96^{\mathrm{a}}$ & $1.36^{\mathrm{a}}$ & $1.74^{\mathrm{a}}$ & $1.60^{\mathrm{a}}$ \\
\hline $\mathrm{B}_{2 \text { (evening) }}$ & $2.36^{\mathrm{a}}$ & $2.10^{\mathrm{a}}$ & $2.44^{\mathrm{a}}$ & $1.82^{\mathrm{a}}$ & $1.96^{\mathrm{a}}$ & $1.80^{\mathrm{a}}$ \\
\hline
\end{tabular}


Bacteriological quality of vegetable salads sold at restaurants within Okada town, Edo State Nigeria.

\begin{tabular}{|c|c|c|c|c|c|c|}
\hline $\mathrm{C}_{1 \text { (morning) }}$ & $2.08^{\mathrm{a}}$ & $1.12^{\mathrm{a}}$ & $2.24^{\mathrm{a}}$ & $1.44^{\mathrm{a}}$ & $2.10^{\mathrm{a}}$ & $2.36^{\mathrm{a}}$ \\
\hline $\mathrm{C}_{2 \text { (evening) }}$ & $2.10^{\mathrm{a}}$ & $1.86^{\mathrm{a}}$ & $2.60^{\mathrm{a}}$ & $2.02^{\mathrm{a}}$ & $2.34^{\mathrm{a}}$ & $2.90^{\mathrm{a}}$ \\
\hline
\end{tabular}

Mean counts succeeded by alphabet "a "are not significantly different ( $\mathrm{P}>0.01)$ from each other using ANOVA TCC: Total coliform count, THC: Total heterotrophic count

\section{FIGURES}

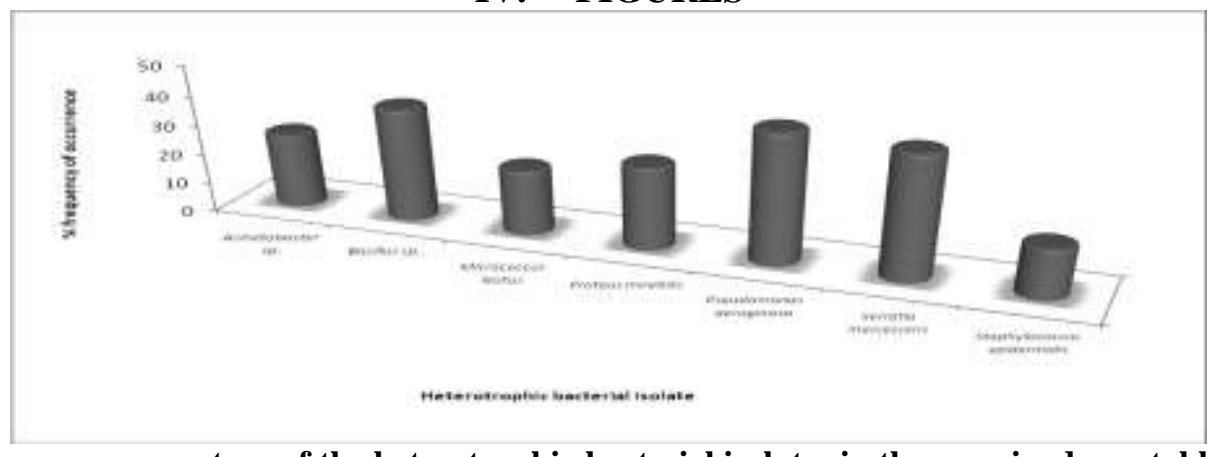

Fig. 1: Occurrence percentage of the heterotrophic bacterial isolates in the examined vegetable salads.

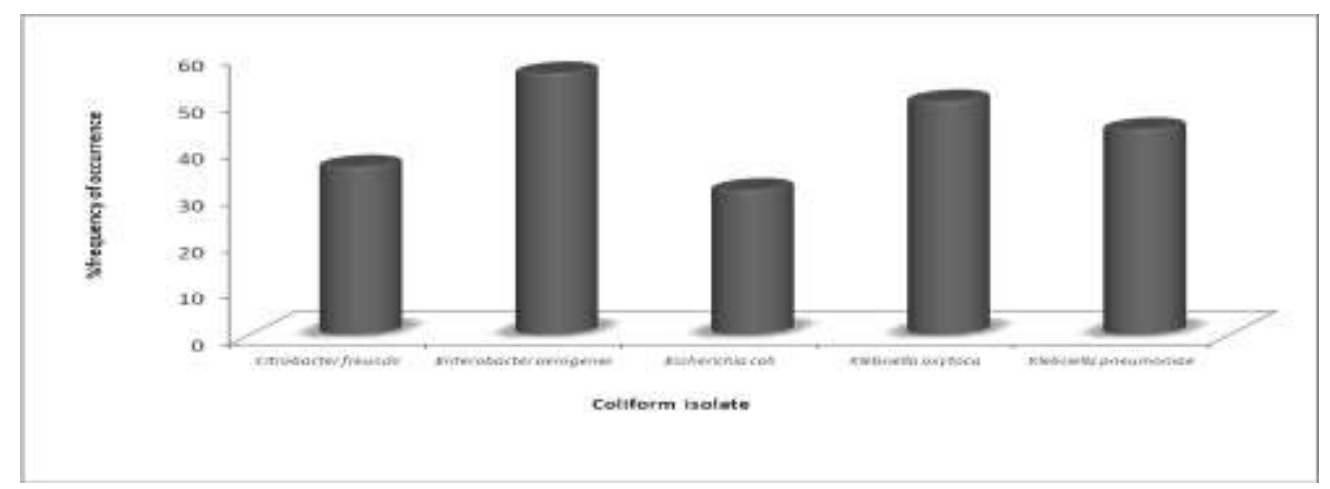

Fig. 2: Occurrence percentage of the coliforms in the examined vegetable salads.

\section{Results and Discussion}

The results of the mean heterotrophic bacterial and coliform counts were shown in TABLE 1. It revealed that HPC and TCC of vegetable salads obtained from restaurant A at both the morning (10:00 am) and evening (4:00pm) periods during the sampling months (May-July, 2012) ranged from $2.80 \times 10^{4}$ to $1.46 \times 10^{4}$ $\mathrm{CFU} / \mathrm{g}$ and $1.46 \times 10^{4}$ to $2.84 \times 10^{4} \mathrm{CFU} / \mathrm{g}$, respectively. The mean heterotrophic and coliform counts observed for vegetable salads collected from restaurant $\mathrm{B}$ at the morning and evening times during the sampling months ranged from $1.74 \times 10^{4}$ to $2.36 \times 10^{4} \mathrm{CFU} / \mathrm{g}$ and $1.36 \times 10^{4}$ to $2.10 \times 10^{4} \mathrm{CFU} / \mathrm{g}$. Ranges of heterotrophic and coliform counts; $2.08 \times 10^{4}$ to $2.60 \times 10^{4} \mathrm{CFU} / \mathrm{g}$ and $1.12 \times 10^{4}$ to $2.90 \times 10^{4} \mathrm{CFU} / \mathrm{g}$ were recorded for vegetable salads obtained from restaurant $\mathrm{C}$ at both morning and evening times during the sampling period under review. The differences in the mean total heterotrophic counts and coliform counts recorded for the vegetable salads collected from the respective food centers was statistically insignificant ( $\mathrm{P}>0.01)$ (TABLE 1).

Seven non hemolytic heterotrophic bacterial isolates; Acinetobacter sp., Bacillus sp., Pseudomonas aeruginosa, Proteus mirabilis, Serratia marcescens, Staphylococcus epidermidis and Micrococcus leutus were identified from the respective vegetable salads. Also, five non hemolytic coliform isolates; Enterobacter aerogenes, Escherichia coli, Citrobacter freundii, Klebsiella pneumoniae and Klebsiella oxytoca were recovered from the vegetable salads. Amongst the heterotrophic bacterial isolates; Pseudomonas aeruginosa exhibited the highest percentage of occurrence $(44 \%)$ while S. epidermidis had the lowest percentage of occurrence (17\%) (Fig.1). E. aerogenes displayed the highest percentage of occurrence (56\%) whilst E. coli exhibited the lowest percentage of occurrence (31\%) amongst the coliform isolates (Fig. 2).

The microbial counts recorded for the vegetable salads obtained from the respective restaurants (TABLE 1) are indicative of the fact that the microenvironments within these foods provided favorable conditions for the growth and proliferation of diverse groups of bacteria. Although the bacterial isolates recovered from the respective salads were non hemolytic, the high heterotrophic bacterial counts recorded for all the vegetable salads could be reflective of the exposure rate of these salads to any form of contamination. Halablab et al. [3] reported that total coliform counts can be considered as a hygiene indicator especially for fecal contamination. In this study the coliform counts observed for the vegetable salads (TABLE 1) could suggest a high level of background fecal contamination of the vegetables used in the preparation of the commercially available salad preparations. A potential source of the contamination could be from water used in 
the growing and processing of the vegetable plants prior to sale. European Commission [18] stated that cutters and slicers used in the preparation of vegetables for salad dressings can be potent sources of contamination, since they usually provide inaccessible sites, which harbor bacteria. The presence of cut surfaces provides an increased surface area for contamination and growth and allows microbial infiltration of the tissues [18].

Garg et al. [19] and Farmer [20] reported that exposing vegetables to various types of cutting has been shown to result in a six to seven-fold increase in microbial numbers. The presence of these coliforms especially E. coli could also be attributed to human and animal fecal contamination as these coliforms are usually present in large numbers in fecal matter. The coliforms isolated from the vegetable salad were also observed to be non hemolytic. These results are in agreement with a previous report by El Gohany [21] who reported that food materials of plant and animal origins either cooked or uncooked are predominantly contaminated by coliforms which are mainly non hemolytic.

Generally, the microbial counts of the vegetable salads collected during the evening time (4:00pm) were higher than the microbial counts observed for the salads collected from the restaurants at morning time $(10: 00 \mathrm{am})($ TABLE 1$)$. This trend could suggest that the vegetable salads were stored at holding temperatures which favored the proliferation of the microbial load of the respective vegetable salads. James and Ngarmsak [2] observed that storage temperature and $\mathrm{pH}$ are the two principal determinants of growth for food-borne pathogens associated with fresh produce. The dominance of Pseudomonas aeruginosa and coliforms amongst the bacterial genera identified from the vegetable salads (Fig. 1 and 2) is not surprising as Lund [22] reported that the majority of bacteria found on the surface of plants are usually Gram-negative and belong either to the Pseudomonas group or to the Enterobacteriaceae.

\section{Conclusion}

This study revealed that all the vegetable salads sampled from the restaurants located within Okada town, Edo state, harbored a high microbial load. Although, these microorganisms can be part of the epiphytic flora of the vegetables, their persistence and proliferation is a reflection of poor hygienic practices by both the sellers of the raw vegetables and the food handlers. Also, the microbial counts of the vegetable salads collected during the evening time were higher than those collected from the restaurants at morning time. Food handlers within the respective restaurants should employ appropriate holding temperatures which would discourage the increased growth of the bacterial flora of the vegetable salads. Vegetable salad leftovers should be disposed off instead of being kept in cold storage and sold the following day.

\section{References}

[1] R.E. Uzeh, F.A. Alade and M. Bankole, The microbial quality of pre packed mixed vegetable salad in some retail outlets in Lagos Nigeria. African Journal of Food Science, 41, 2009, 270-272.

[2] J.B. James and T. Ngarmsak, Processing of fresh cut tropical fruits and vegetables: A technical guide (Bangkok: FAO, 2011).

[3] M.A. Halablab, I.H. Sheet and H.M. Holail, Microbial quality of raw vegetables grown in Bekaa valley, Lebanon. American Journal of Food Technology, 6, 2011, 129-139.

[4] C. DeRoever, Microbiological safety evaluations and recommendation on fresh produce. Food Control, 9, $1999,321-347$.

[5] P.D. Mensah, K. Yeboah-Manu, S. Owusu-Darko and A. Ablordey, Street foods in Accra, Ghana: How safe are they? WHO Bulletin, $80,2002,546-554$.

[6] G.S. Johannessen, S. Loncarevic and H. Kruse, Bacteriological analysis of fresh produce in Norway. International Journal of Food Microbiology, 77, 2002, 199-204.

[7] V. Poorna and A. Randhir, Prevalence and growth of pathogens on salad vegetables, fruits and sprouts. International Journal of Environmental Hygiene and Health, 203, 2001, 205-213.

[8] R. Bibek, Fundamental food microbiology (London: CRC Press, 2005).

[9] C. Nguyen-the, and F. Carlin, The microbiology of minimally processed fresh fruits and vegetables. Critical Reviews in Food Science and Nutrition, 34, 1994, 371-401.

[10] A.M. Al-Binali, C.S. Bello, K. El-Shewy and S.E Abdulla, The prevalence of parasites in commonly used leafy vegetables in south western Saudi Arabia. Saudi Medical Journal, 27, 2006, 613-616.

[11] G. Tortora, Microbiology (New York :The Benjamin Publishing Co. Inc., 1995)

[12] J.P. Harley and L.M. Prescott, Laboratory exercises in microbiology $5^{\text {th }}$ ed. (New York: Mac Graw Hill, 2002).

[13] P. Sharma, Manual of microbiology, tools and techniques. (New Delhi : Ane books. Pvt. Ltd., 2009).

[14] M. Cheesebrough, District laboratory practice in tropical countries, Part II. (Cambridge :Cambridge Univ. Press, 2000)

[15] D.R. Cullimore, Practical atlas for bacterial identification (Florida; CRC Press 2000).

[16] K. R. Aneja, Experiments in microbiology, plant pathology and biotechnology, $4^{\text {th }}$ ed. (New Delhi: New Age Pub. Ltd., 2003).

[17] D. Roberts and M. Greenwood, Practical food microbiology $3^{\text {rd }}$ ed. (Oxford: Blackwell Publishing Ltd., 2003).

[18] European Commission (EC), Risk Profile on the microbiological contamination of fruits and vegetables eaten raw (http.//europa.eu.int/Comm/food/fa/sc/scf/Index en. html., 2002).

[19] N. Garg, J.J. Churey and D.F. Splittstoesser, Effect of processing conditions on the micro flora of fresh-cut vegetables. Journal of Food Protection, 53, 1990, 701-703.

[20] J.J. Farmer, Enterobacteriaceae: Introduction and identification, in P.R. Murray, E.J. Baron, M.A. Pfaller, F.C. Tenower and R.H. Yolken (Eds). Manual of clinical microbiology, 6. (Washington D. C: American Society for Microbiology, 1995) 438-448.

[21] A.H. El Gohany, Sausage and minced meat as a source of food poisoning microorganism to man. Journal of Assiut Veternary Medicine. 30, 1994, 146-215.

[22] B.M. Lund, Ecosystems in vegetable foods. Journal of Applied Bacteriology, 73, 1992, 115-135. 